\title{
Determination of virulence factors of Escherichia coli isolated from urinary tract infection patients
}

\section{ANIL CHATURVEDI, ANKITA GAUTAM, SANGEETA SHUKLA AND VINAY KUMAR SINGH}

See end of the paper for authors' affiliation Correspondence to : ANIL CHATURVEDI Sam Higginbottom Institute of Agriculture Technology and Sciences, ALLAHABAD (U.P.) INDIA

Email:

anilchaturvedi15@gmail.com
ABSTRACT : Urinary tract infections are one of the most common bacterial infections in human. On the present study urine sample of suspected UTI patients were included. Total 23 samples were found to be positive for bacterial infection in which predominant species was Escherichia coli $13(56.52 \%)$ and $10(43.48 \%)$ were found to be other bacterial species i.e. Proteus spp. 4 (17.3\%), Citrobacter spp. 3 (13\%), Klebsiella spp. $1(4.3 \%)$, Enterobacter spp. 1 (4.3\%), and Staphylococcus aureus 1 (4.3\%). The isolates identified as Escherichia coli were screened for virulence factors namely cell surface hydrophobicity, haemolysin and gelatinase production by recommended methods. Among 13 E. coli 8 (61.54\%) were showing cell surface hydrophobicity, 10 (76.92\%) were haemolysin positive and nil result for gelatinase production was observed. The study reveals hydrophobicity and $\alpha$ - haemolysin production in E.coli strains which are important virulence factors in the pathogenesis.

How to cite this paper : Chaturvedi, Anil, Gautam, Ankita, Shukla, Sangeeta and Singh, Vinay Kumar (2014). Determination of virulence factors of escherichia coli isolated from urinary tract infection patients. Internat. J. Med. Sci., 7(1\&2) : 47-50.

\section{KEY WORDS :}

Escherichia coli, Urinary tract infection,

Hydrophobicity, Virulence factor, Haemolysis. 